\title{
Encountering the state through legal tenure security: perspectives from a low income resettlement scheme in urban India
}

Keywords: tenure security, resettlement, governance, the state, control, India

\begin{abstract}
:
Tenure security systems - which determine who lives where and under what terms and conditions - are processes of governance that make and effect the relationship between those who confer tenure security and those on who tenure security is conferred. Yet, in dominant analyses of land and housing tenure security, and in policy recommendations for property rights and legal tenure security in developing countries, governance implications are overlooked in favour of analyses of the relative merits of different tenure systems mainly in terms of security, livelihood and economic impact. Using interview data and observations from a resettlement scheme in Ahmedabad, India, this paper empirically examines citizen-state relations in the context of a major shift from de facto (in practice) to legal tenure security and asks how do citizens who have recently come to live under legal tenure security encounter the state and make sense of it. I find a bureaucracy of tenure security that exerts control over low income citizens largely through fear. However, such control is incomplete and acts of resistance suggest an emerging 'paralegal' space to renegotiate tenure rules. I conclude by examining the findings through a conceptual framework that explains the relationship between state power and legal tenure security. I also discuss the need for greater scrutiny of the political effects of urban land and housing tenure systems on poor people.
\end{abstract}

\section{Introduction}

Legal, sometimes called 'formal', tenure security is a component of legal property rights (rights that are enforced and protected by the state) and has been upheld as an ideal condition for governments of developing countries to aspire towards in their land and housing policy since the 
1970s, when housing scholarship first started to examine conditions of 'informality' in lowincome settlements in South America (e.g. Turner, 1976, in Peru; Karst, 1971, in Venezuela). The conclusions reached by that scholarship resulted in World Bank-led interventions such as site and service schemes and later informal settlement upgrading across the global south. Such schemes awarded legal tenure security via property titles on the understanding legal tenure inspires confidence in structure-owners to then make improvements to and investments in physical housing, subsequently enabling household wellbeing and prosperity (Gulyani \& Bassett, 2007; Stren, 1990; Tipple, 1994). Under a human rights based agenda in international development, and convinced by the economic (de Soto, 2000) and social benefits (Allendorf, 2007) of property rights, advocacy for legal tenure security continues to be the official position of international development actors including the World Bank, the UK Department for International Development, the International Fund for Agricultural Development and UNHABITAT, who, through aid budgets and loans that finance development interventions, carry influence over national governments in developing countries (see International Fund for Agricultural Development, 2015; The World Bank, 2011; UN-HABITAT, 2010; UKAid, 2015).

The universal adoption of the Sustainable Development Goals in 2015, underlines the point. Goal 1 to end poverty in all its forms everywhere, includes the target to "ensure that all men and women, in particular the poor and the vulnerable, have equal rights to economic resources, as well as access to, ownership and control over land and other forms of property, inheritance, [and] natural resources." (UKAid, 2015:6). The proposed indicator for the target includes the "percentage with legally documented or recognised evidence of tenure" (Ibid, emphasis added). While this can allow for the recognition of non-legal tenure as adequate evidence of access to, ownership and control of property, it is worth noting that recognition of other tenure types has not displaced development programmes supported by international development actors that focus mainly on legal tenure security. The links between legal tenure security and a plethora of developmental goods such as sustainable development, wellbeing and poverty reduction, appear 
entrenched in development discourse and practice. This is despite the ambiguity in on-going empirical scholarship on definitions of what actually constitutes tenure security and the role of legal property rights therein (Van Gelder \& Luciano, 2015; Van Gelder, 2010).

Van Gelder's (2010) typology of tenure as legal, de facto and perceived, while adding clarity of definition, simultaneously underscores the fact that there is no conclusive evidence on which type of tenure security is best. Rather, his findings chime with a nuanced scholarship that acknowledges de facto tenure systems (those found on the ground in practice), customary or neo-customary systems can provide the same or improved outcomes as claimed by legal tenure security. For example, protection from eviction (Payne, 2001; Durand-Lasserve and Royston, 2002), confidence that results in investments to property (Payne, Durand-Lasserve \& Rakodi, 2009), access to finance (Gilbert, 2002), and associated benefits in improvements to gender equality within a household and community (Lastarria-Cornhiel, 1997; Varley, 2007), access to infrastructure (Varley, 2002) and health care (Porio \& Crisol, 2004). And, in the case of customary and neo-customary tenure, postcolonial scholarship argues these systems carry a greater legitimacy with local populations than a legal regime rooted in colonial land and property law (Home, 2004).

Against the powerful tide of preferences for legal tenure security and property titles, scholarship examining the relative merits of different systems against their theorised outcomes is necessary. However, the concern of this paper is not the relative merits of legal tenure security vis-à-vis other systems. Instead, it examines the relationship between citizen and state in the context of the award of legal tenure security in a low-income settlement on the basis that the governance implications of a shift from systems based on claims to residential space (de facto tenure) to systems based on legal rights to residential space has received insufficient empirical study. Governance is defined as both a technique of rule exercised by governments over citizens, and a process or practice that makes the state real to people (Hansen and Stepputat, 2001:5). In the 
context of this study, a legal tenure system is both a governing technique of rule that makes explicit the legal rights and responsibilities between citizen and state in the exercise of property rights, and a process through which citizens come to learn of, engage with and understand aspects of the state.

Current literature on governance and tenure tends to focus on governance as a technique of rule. For example, Van Leeuwen (2014) discusses the effect of tenure reform on local governance systems in Uganda, specifically the position and power of local elites and state actors, but not the affected residents' subsequent engagement with 'the state'. Earle's (2014) discussion of the proposed tenure regularisation of informal settlements in Mozambique unpicks the complex layers of governance in informal spaces that determine tenure security and questions the appropriateness of the state's award of legal tenure, but does not examine the relationships between citizen and the state ex-post nor ideas of 'the state' inherent in legal tenure. In the Indian context, Weinstein's (2009) detailed analysis of local state and civil society relations in the development of Mumbai's infamous informal settlement, Dharavi, illustrates the mechanics of governance as local state officials attempt to engage with Dharavi's residents on redevelopment plans including clearer tenure rights. Nakaruma's (2016) study of Pune similarly shows the importance of local state officials both within the municipality and local politicians in making improvements to informal urban settlements and their role in supporting improved tenure security. Where tenure is discussed in these studies it is typically as an outcome of negotiations or interactions between local state actors and residents. The altered relationship between citizen and the state following changes to tenure and urban (re)development is rarely featured and governance is not fully discussed as a practice through which citizens come to know the state.

This paper empirically examines legal tenure as a technique through which people are governed by the state following their resettlement to a low income housing development, and how this process affects new interactions with aspects of the state and builds an understanding of what 
the state is. The question guiding this study is: how do citizens who have recently come to live under a legal tenure security encounter the state ${ }^{1}$ The answer carries implications for the advocacy for legal tenure security and sheds light on exercises of state power over the urban poor via the medium of land and housing tenure systems. The remainder of the paper is structured thus: after this introduction, I present a conceptual framework to explain the motivations of the state to award legal tenure to poor urban dwellers. Following a brief discussion of the research methodology and methods, the research site - Vatva, in Ahmedabad, north-west India - is presented alongside empirical evidence of legal tenure security in action. Findings show that the bureaucracy of legal tenure security employed by the state exerts control over low income citizens largely through fear. However, control is incomplete and acts of resistance suggest an emerging 'paralegal' space (as understood by Partha Chatterjee, 2004) to renegotiate tenure rules. In the conclusion, I refer back to the conceptual framework to explain the rationale underlying residents' encounters with the state and make a case for greater scrutiny of the political effects of urban land and housing tenure systems on poor people.

\section{State motivations for the award of legal tenure security: a conceptual framework}

This section examines the state's motivations for advocating and implementing programmes that award legal tenure security to the urban poor by drawing upon relevant literature on tenure security and literature in political science and anthropology on 'the state'. The conceptual framework that subsequently develops is applied in part $\mathbf{6}$ to Vatva to help explain the rationale underlying the empirical reality of how residents living under legal tenure security encounter the state.

It is relevant to note the role of the state is not formally established in any one tenure system. For example, in both formal and informal settlements, municipalities have been known to provide drinking water, enumerate property and collect local property tax (Benjamin, 2008;

\footnotetext{
${ }^{1}$ By focusing on those eligible to a state-led resettlement scheme, a citizen is defined as an Indian national.
} 
Varley, 2002), thus providing marks of tenure security. However, within a legal system, the role of state actors tends to be more clearly defined for example, legal systems necessarily involve the judiciary in legislating and upholding property rights, central ministries and decentralised departments document property ownership via cadastral surveys and property registers, and municipalities collect and spend property tax from legally recognised owners. Overall, the distinguishing feature of a legal tenure system over other systems is the assumed legitimacy of the actions of the state. Here the paper draws upon the argument made by Roy (2005) that the state produces informality and formality (and illegality and legality) through an exercise of its own power. Thus, in the context of the production of legal tenure security the state exercises legitimate power over where people live, for how long, and under what terms they live there, and so "it becomes apparent that the legalization of informal property systems is not simply a bureaucratic or technical problem but rather a complex political struggle" (Roy, 2005:150). From a review of literature, three dominant explanations for why the state might craft a legal tenure system to pull in low income citizens previously living under different tenure arrangements emerge.

\subsection{Legal tenure security for political settlement}

The first explanation concerns a political settlement that aims to uphold the rights and responsibilities between citizen and state. Most states in the world have ratified at least one international treaty or convention ${ }^{2}$ and/or committed to a declaration ${ }^{3}$ that explicitly affirms all people's right to adequate housing, which includes an entitlement to tenure security - defined as how dependable peoples' claims are to enjoy or own land or a residence without fear of forced eviction, harassment or other threats (OHCHR, 2009:3). In countries such as South Africa and Mexico, the right to adequate housing is codified into national Constitutions. In India, the

\footnotetext{
${ }^{2}$ For example, the 1948 Universal Declaration of Human Rights, Article 25, recognises adequate housing as part of the right to an adequate standard of living.

${ }^{3}$ For example, the 1996 Habitat Agenda which states, "Within the overall context of an enabling approach, Governments should take appropriate action in order to promote, protect and ensure the full and progressive realization of the right to adequate housing” (UN-HABITAT, 1996, Paragraph 61)
} 
constitutional obligations of the state are couched more implicitly in the all-encompassing right to the protection of life and personal liberty (Article 21), which declares, "No person shall be deprived of his life or personal liberty except according to procedure established by law" (GoI, 1949). The inclusion of a right to housing within a fundamental right to life has been established in a number of Supreme Court rulings establishing precedence (Kothari, Karmali and Chaudhry, $\left.2006^{4}\right)$.

Notwithstanding a state's upward accountability to international legislation to establish a legal framework that protects tenure security for, particularly, weaker members of society, states may also draw citizens into legal tenure security as part of a progressive commitment to the inclusion of socially excluded citizens into a modern state (Royston, 2002 and Author, 2015, discuss this with reference to South Africa). In India, as intended by one of the chief architects of the Indian Constitution, B.R. Ambedkar, drawing low income citizens, particularly those labelled Scheduled Caste or Scheduled Tribe into the remit of a modern secular state governed by the rule of law, may be part of building an inclusive citizenship, where Scheduled Castes and other groups who are exposed more than other citizens to exploitation and injustice have at least rights in law, as a precursor to the social and political exercise of those rights (Roy, 2014).

\subsection{Legal tenure security for economic development}

The second explanation is that drawing low income citizens into a legal tenure system is part of a strategy for economic development. In an economically liberal and liberalising state, as the Indian state after 1990 is often described (Corbridge \& Harriss, 2000), property rights and tenure security protected by law have at least two potential economic gains for citizens and for the state: the former can more effectively raise finance using their property as collateral which can be reinvested to build individual or household assets, and the latter can raise municipal finances

\footnotetext{
${ }_{4}^{4}$ These authors list many examples of case law including the 1990 Supreme Court case Shantistar Builders v. Narayan Khimalal Totame in which the court judgement, drawing upon Article 21, ruled "The right to life would take within its sweep the right to food, the right to clothing, the right to decent environment and a reasonable accommodation to live in." (Kothari et al, 2006:34).
} 
through property tax and real estate development, for example, to fund services and invest in urban renewal. The economic gains for citizens from a legal tenure system has been argued vociferously by the highly influential Hernando de Soto, whose ideas some 15 years after the publication of The Mystery of Capital (2000) are still relevant to tenure security debates (despite extensive empirical and theoretical critique his ideas have received since that book's publication, see Gilbert, 2012). In developing countries that pursue liberal agendas, de Soto maintains that only through inclusion into a legal property system, which offers the highest tenure security, can the poor access formal credit and release the 'dead capital' locked in their land and housing, and so overcome their poverty. He articulates a simple solution of self-help among the poor within an all-encompassing state apparatus that eliminates 'extra-legality' and unenforceable social contracts that otherwise govern property markets (de Soto, 2000:86-94).

For the state, in a context of decentralised government, which is a globally popular governance reform agenda, Indian municipalities are increasingly charged with administrative and fiscal responsibilities for their locale, and for directing and overseeing urban renewal, which is identified in the Government of India's Eleventh Fifth Year Plan (2007-2012) as essential to support the urban investments driving economic growth in the country (Kundu and Samanta, 2011; Maringanti, 2012, Nandi and Gamkhar, 2013). Writings on Indian decentralisation, urban investment and strategies for economic growth, highlight different approaches Indian local governments have taken to increase revenue and fund urban renewal, with a range of effects on poor urban citizens and their property rights. Such approaches include: developing real estate, an activity associated with creating a positive environment for international and domestic investment and entrepreneurial activities (and which often includes formally recognising and subsequently relocating residents of informal and unsightly settlements to urban peripheries and off highly profitable land, Kundu and Samanta, 2011:55); imposing user fees for municipal basic services (Maringanti, 2012:104); and, increasing property tax collection. 
Property tax is one of the main ways in which municipalities can raise revenue to pay for local services and assert autonomy from central government (Robbins, 2014). It is also a key mechanism to realise the democratic potential of local governance by enabling a local government to be more responsive to citizen needs and demands (Crook and Manor, 1998). As noted by Earle (2014) with reference to the regularisation of informal settlements in Maputo, increasing the municipal tax base is an effective argument for drawing informal dwellers into a legal structure that records them in a property tax regime. In Ahmedabad, the Ahmedabad Municipal Corporation (AMC) has targeted reforms in property tax in recent years in a drive to increase municipal revenue. In this regard, the AMC first updated municipal property records and added "a large number of previously unrecorded properties" (GLTN and UN-HABITAT, 2011:106), reassessed the value of properties, and then implemented punitive measures for tax defaulters. These efforts increased the tax base of the AMC from 37\% of assessed properties that paid tax in 2004-5 to 55\% in 2007-8 (Ibid.). In Ahmedabad, people living in informal settlements, even if they are connected to municipal services, do not pay property tax or service charges. People who own housing that is recorded in the municipal property register are subject to property tax.

\subsection{Legal tenure security to manage informality}

This explanation of the state's motivation to expand the provisions of legal tenure security demands contextualising the potential political and economic gains and losses of a shift to legal tenure security within a much larger discussion of governance and the role of the state. In Seeing Like a State, James Scott (1998) argues that states act to implement rational order over society to facilitate 'High Modernism', and the tools for rational order include codified rules, maps and ledgers that make society 'legible' to outsiders. This lens through which we might view the state is relevant to debate over tenure regimes, particularly where codified rules in legal tenure security are privileged over localised and socially complex tenure arrangements found in informal 
settlements. The concept of 'informality', Ravi Kanbur (2009) has argued from an economic perspective, denotes the absence of state regulation and the loss of a government's function. Whereas, James Holston's (2008) anthropological perspective, suggests living informally is part of an insurgent citizenship that can represent spaces of resistance to the power of the state. From these two very different perspectives on the value of informality there is a common idea: that informality represents a social order that competes with the authority and legitimacy of the state. Thus, subsuming informal tenure arrangements into a legal tenure regime can be regarded as consolidating state authority over all citizens and the incorporation of spaces of opposition into the purview of the state. Through Scott's (1998) lens, drawing people into the formal legal system is a technique of rule, and part of an agenda of state control and an assertion of the power of statehood, which may be for socially progressive or nefarious purposes.

However, the 'state' in Scott's (1998) analysis is fixed as a monolithic entity, one capable of central planning (though not with positive outcomes) and moves with single purpose. Whereas, studies on the Indian state have shifted from analysing India as a developmental state which in the first 40 years after Independence followed Jawaharlal Nehru's vision of paternal modernism where the state brings forth 'development' to backward people and places (Corbridge \& Harriss, 2000), to a more critical reading of the state (Robbins \& Rice, 2007). This turn from 'seeing like a state' to Seeing the State (Corbridge, Srivastava, Williams, \& Véron, 2007), focuses on the perspective of citizens who encounter the state through its multiple representations and in a variety of everyday experiences such as finding a place to live, to work, to educate oneself and family, and to stay healthy.

Plural representations of the Indian state is well established by authors who draw upon poststructural analysis of the state and power (e.g. Sharma and Gupta, 2005; Ferguson \& Gupta, 2002; Corbridge et. al, 2005; Chatterjee, 2004). In this type of analysis the state is culturally formed and realised through both its representations in government policy, laws, their 
implementation, localised offices, court buildings and ritualised practices; and, public perception of and engagement with these. This means that the boundaries of the state vis-à-vis society, are not easily identifiable, and as Fuller and Harriss (2001) note with specific reference to the postcolonial Indian state, this makes it a very difficult entity to study. Nonetheless, by focusing on a particular aspect of the state, ethnographic studies of the Indian state have drawn out the ways in which the state is made through its representations and in public imaginations (e.g. Benei and Fuller, 2001). To Thomas Hansen, the public imagination of the Indian state comes from both its sublime and profane dimensions: the sublime exists in the perceived qualities and values of the state (such as, its high authority and figure as arbitrator of fairness), and the profane in the "banality of the technical sides of governance" (Hansen, 2001:35). In this study, and consist with Hansen's use of the term, the concept of governance has two mutually reinforcing aspects: it is a technique used to exercise the state's rule over a population, and a practice through which a population comes to imagine what the state is. That is, the technical side of governance is the profane medium through which the state exercises its sublime values, which in the context of managing informality through legal tenure systems means exercising the state's high authority over who lives where and how.

Partha Chatterjee's (2004) influential work on governance, the state and Indian citizens similarly argues that the state governs through a "mundane administrative reality" (2004:36). Echoing the idea of informality as a social order that rivals state control, he denotes spaces where the state's governance is incomplete and where context-specific rules govern aspects of people's lives as “zones of paralegal practices" (2004:128). In this space,

...there are attempts [...] to devise new, and often contextual and transitory, norms of fairness and justice in making available the welfare and developmental functions of government to large sections of poor and underprivileged people. (2004:128) 
The paralegal thus represents a promising space for citizens to (re)negotiate with the state the exercise of rights and responsibilities and re-forge the technical rules of their governance.

To Akhil Gupta (2006), state administration is not only a mechanism for governance as Chatterjee notes, but that government bureaucracy at the local level is actually how the majority of Indian citizens encounter the state and give meaning to what the state is. Bureaucracy is defined by Wendy Brown (1995/2006) as the tangible institutions, processes and procedures that rationalise the exercise of power and act as the mechanisms for its application. It is the bureaucratic machine of the state, she argues, that normalises its exercises of power. So, by examining the bureaucracy of tenure security this paper builds an empirical base for better understanding the interactions of marginalised members of society with the state in India, and a citizen-focused conceptualisation of the state and its motivations.

Figure 1: State motivations for the award of legal tenure security: but what motivations are apparent through poor citizens' encounters with the state?

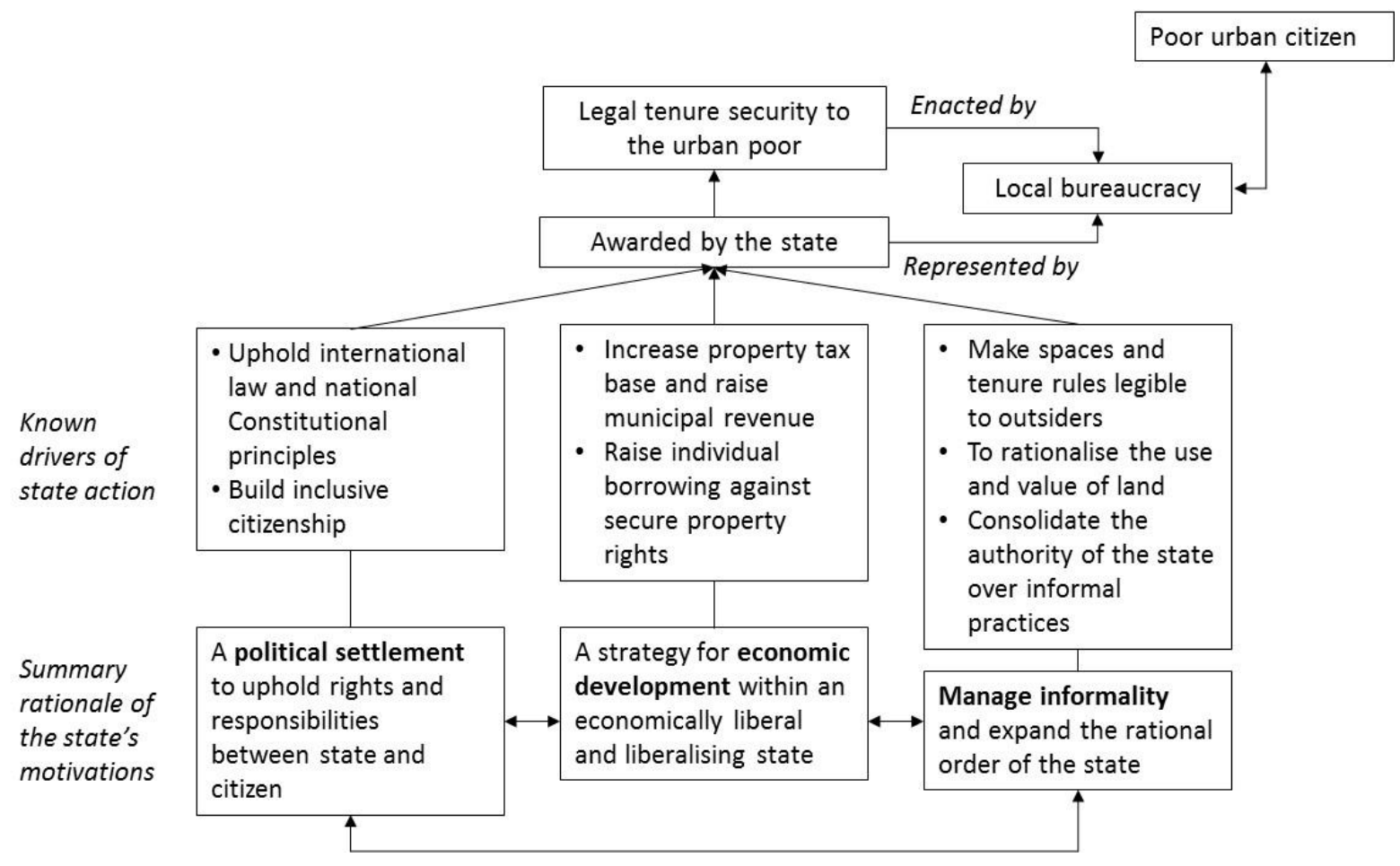


The conceptual framework, explained in figure 1, summarises the three dominant explanations in literature on tenure security and the state for why the state might draw low income citizens into the state's preferred tenure system: to engender a political settlement, as part of a strategy for economic development and to manage informality. What is evident is there is no single rationale for the motivations of the state, for these explanation can work in combinations and overlap. The paper is most concerned with the position of poor urban citizens and whether in their encounters with the state (as represented in local bureaucracy of tenure security) the drivers (or variables) of state action are recognisable. And from their encounters, what rationale for the state's actions are subsequently apparent.

\section{Methodology and methods}

This study of the state and its exercise of power through legal tenure security is built through a constructivist lens in complement with retroductive logic where observations of social relations and social arrangements are recounted and then explained through models or hypotheses (Blaikie, 2000; 2007). The aim of constructivist retroduction is to discover through observation the hidden mechanisms that in certain contexts explain observed regularities. In this paper, constructivist-retroduction means to first explore observations of residents' encounters with tenure security and the state, and the second is to explain what was observed i.e. to call upon the conceptual framework of the state's exercises of power in the field of tenure security to explain residents' encounters.

Empirical data is drawn from two periods of fieldwork in Ahmedabad in Spring 2014 and 2015. The research methods employed were non-participant observation at the field site and 24 semistructured interviews with residents in Vatva and AMC officials. Observations were recorded in a field diary to contextualise interview data and to generate a thick description of Vatva and experiences of tenure security. 16 interviews were conducted with eight residents on a recurring basis, also three residents and five officials were interviewed once. All interviews lasted one hour 
to one hour and 30 minutes each. 22 of the interviews were conducted in Gujarati and later translated into English by my research assistant and me, the remainder were conducted in English. Respondents in the study site were identified through purposive sampling where we would approach residents formally living at the site (i.e. those residents officially named as residing at the property and not renters or squatters). Respondents reflect a mix of identities within the Economically Weaker Section (EWS) ${ }^{5}$ category by gender, age, religion, caste, noncaste affiliation and state-origin (i.e. a mix of Gujaratis and non-Gujaratis). Officials were identified across different scales of operation: district officers responsible for collecting property payments in southern Ahmedabad, the AMC's Chief City Planner, and the Mayor of Ahmedabad who is also Chairperson of the AMC. Copies of official AMC documents issued to residents that govern the resettlement process and the terms and conditions of living in resettled housing were also obtained and analysed for discourses of the state and tenure security.

\section{Introduction to the research site}

\subsection{Ahmedabad}

Ahmedabad is the commercial capital of Gujarat state, a state with a strong reputation as a driving force in India's story of economic growth since the 1990s. The pro-business outlook of the former Chief Minister of Gujarat (and current Prime Minister), Narendra Modi, has long been associated with the story of Gujarat's successful economy. Despite evidence that tempers claims of 'the Modi effect' on Gujarat's economy (see Ghatak and Roy, 2014), within a national and international discourse of 'India Rising', Ahmedabad is marked as an important 'megacity' worthy of major state investment (Yagnik and Sheth, 2011).

Ahmedabad is one of 65 mission cities selected by the Jawaharlal Nehru National Urban Renewal Mission (JNNURM) for urban transformation. Formulated in 2005 and extended to March 2017, the JNNURM operates through its two submissions: Urban Infrastructure and

\footnotetext{
${ }^{5}$ People in this category earn less than 1 lakh $(100,000)$ rupees per annum.
} 
Governance which is focused on infrastructure upgrading (e.g. road networks, sewerage, transport and water supply) and the Basic Services for the Urban Poor (BSUP) which funds the development of low income housing across Ahmedabad for those affected by sub-mission one (known as 'project affected people' in the state's parlance) (Mahadevia, 2011). The BSUP promises through in situ upgrade or relocation improved housing, water supply and sanitation, and affordable tenure security to poor urban households in a bid to create 'inclusive cities' (GoI, 2009:2). Coupled with this idea is 'slum free cities', which can be interpreted as a poverty reduction agenda, where slums are upgraded to adequate and affordable housing, where it suits local political and economic conditions to do so (Desai, 2012). In Ahmedabad, the creation of a slum free city aligns with the resettlement of poor urban dwellers from city centre locations to where most BSUP housing is built on the perimeter of the city (Aloria, 2013, claims on the only land that is affordable); conflating poverty reduction with poverty relocation ${ }^{6}$.

The spatial politics of urban housing, particularly low income housing, and its relationship to the modernisation and economic development of the city is historically significant in Ahmedabad. This industrial city was internationally renowned for its textiles, and the first mills were built in 1859 (gradually falling into decline in the 1980s, Yagnik and Sheth, 2011:156-176). At that time, low income housing in the city consisted of chawls (tenement housing) and slums concentrated within the walled old city on the eastern banks of the Sabarmati River; they were insufficient in number, over-crowded, of a poor quality and affected by water-borne disease (Bhatt, 2003). McGowen writes (2013:402), "bad housing undermined health, resulting in workers who were too weak to be efficient and too often ill to work regularly, thus disrupting production". This prompted an alliance of mill-owning industrialists, mill-worker trade unions and municipal leaders to actively intervene in the low income housing sector. Industrialists built some of the

\footnotetext{
${ }^{6}$ This position signifies a change from Ahmedabad's last major engagement in slum improvement in the mid1990s - the Slum Networking Project - an integrated in situ development which operated through partnerships between the AMC, NGOs, private sector developers and residents (see Chauhan and Lal, 1999, for details of the project and its fundamental challenges to scaling up).
} 
earliest chawls for their workers in the eastern industrial zone of the city close to the textile mills that defined the city's prosperity (Bhatt and Chawda, 1976). And in the 1920s, municipal administrators led by Vallabhbhai Patel acted to improve public health and sanitation in the city through extensive expansion of water and sanitation networks thus directly changing the living conditions of poor Ahmedabadis in city centre housing and crafting inhabitable spaces beyond the old walled city (Yagnik and Sheth, 2011).

As the city's textile industry grew and intra-city links across India improved, the population grew substantially from 590,000 residents in 1941 to well over a million by the 1960s (McGowen, 2013). This burgeoning population contributed to over-crowding in the centre and in the eastern industrial areas of the city. An alliance soon grew between municipal planners and middle and upper class individuals grouped into housing cooperatives to develop new residential suburbs in the 1950s in the hitherto underdeveloped western part of the city across the Sabarmati River, allowing wealthier city centre residents to move. Cooperative membership was strictly defined by caste and religious identity (McGowan, 2013:400); these coops represented sectarian housing solutions to overcrowding. Chandhoke (2009:11) writes that by the late 1960s there were three Ahmedabads: the crowded walled city centre with traditional housing in distinct exclusive class and caste neighbourhoods (known as Pols); dilapidated housing in the industrial townships in the east inhabited by Dalits and Muslim textile workers; and separated by the Sabarmati River, western suburbs where the upper caste and middle class live in well-built bungalows, townhouses and apartments. This spatial segregation, which corresponds to differing levels of service provision, quality of housing and quality of life (Mahadevia, 2002), is still evident.

The spatial footprint of caste and religious based housing has been reinforced through periodic acts of severe communal violence in the city. A historian of Ahmedabad, Howard Spodek (2010:379) writes, 
"For at least two decades, from the Hindu-Muslim violence of 1985 until 2002,

Ahmedabad's social geography had continued to fracture. Hindus perceived danger in living in Muslim majority areas, and, far more typically, Muslims felt even more endangered in Hindu majority neighbourhoods. Waves of migration followed each outbreak of violence as Hindus and Muslims sought the safety of their own homogeneous ghettoes. ... Outside the old city [...] streets that divide the area of one community from the other [were known] as 'borders', and the communities themselves as 'India' and 'Pakistan'. This has become standard terminology even in casual conversation, and a walk down one of these streets immediately confirms the reality of the border and the terminology. Walls have been constructed along many of these border streets, reinforcing the separation. Dalits and Muslims who used to live adjacent to each other have also separated."

Ahmedabad is a spatially divided and divisive city along wealth, religious and caste lines, where the legacy of communalism has accelerated ghettoisation. It is also a megacity in the making, with large-scale investment in urban infrastructure to support Gujarat's story of economic growth. In this context, the BSUP has resettled thousands of low income people previously living in central Ahmedabad to the edges of the city.

\subsection{Resettlement in Vatva}

In the research site, between 2010 and 2011, up to 20,000 people designated EWS were resettled to a new housing development in Vatva, on the south-eastern edge of the city, by the AMC. The land on which they previously resided (typically without any legal title) was acquisitioned by the state for infrastructure development - chiefly the redevelopment of the Sabarmati Riverfront as a commercial and public space, road expansion for a bus rapid transit system and the

\footnotetext{
7 In Varadarajan's (2002) edited collection of vivid and horrific accounts of the 2002 communal riots across Gujarat, Ganesh Devy (2002: 246-266) and Mohandas Namshray (2002: 267-270) illustrate a new feature to the 2002 violence - attacks between Muslims and Dalit and Tribal groups, fragmenting an alliance of the downtrodden that had characterised relations between these three communities in previous episodes of communal violence.
} 
redevelopment of Kankaria Lake into a visitor destination. This resettlement was posited by the AMC as a substantial positive intervention for the individuals concerned (they would move from katcha to pucca housing with secure tenure ${ }^{8}$ ) and for the city, which would now be able to develop its prime locations and attract investment.

The process of resettlement was broadly similar for residents regardless of the infrastructure project that caused their relocation. Typically, in their original residence people were served a notice of eviction by the AMC. This document noted the date after which their jbupdab (or shack) would be demolished and was delivered alongside notice of the process for eligibility to alternative permanent housing or to a temporary site that would lead onto permanent housing. To qualify for BSUP housing residents in Vatva had to provide evidence of their identity and residence to check they were indeed a 'project affected person'. Once eligibility was verified, to access BSUP housing residents had to sign a contract with the AMC consenting to the terms and conditions of their new residence in Vatva, and pay a first instalment of Rs $6900^{9}$ and a maintenance charge of Rs960. To facilitate the process, residents had to provide and bear costs for official stamp paper, photographs and notarised documents. These costs came at the same time they were served notice to vacate the land. At that point, residents "have only two choices: pay the money and live [in BSUP housing], or else don't pay the money and live wherever you like but not in the river front" or anywhere else covered by eviction notices (Chief Planner of the AMC, 10/04/14). The original residences were demolished as soon as legally possible. Payment is the first principle to secure legal tenure rights. Thereafter, 20,000 residents resettled to Vatva are required to make payments over a period of 10 years to total Rs66,900 (minus any subsidy, plus the first payment) to uphold the terms and conditions of their new residence ${ }^{10}$. If all

\footnotetext{
${ }^{8}$ Katcha housing is built using temporary materials, and pucca housing is built using permanent materials. ${ }^{9}$ This figure was lower (Rs3260) for those relocated from the Sabarmati Riverfront, as the development had access to higher subsidies. During the field work periods, the average exchange rate was Rs95 to 1GBP.

${ }^{10}$ BSUP guidelines state that beneficiaries should contribute a minimum of $12 \%$, which is lowered to $10 \%$ for recognised weaker sections of society (GoI, 2009:11).
} 
payments are made full ownership (dustave) is awarded to the resident, until this point residents are in effect tenants of the AMC.

Across the city a similar process is implemented to move thousands into identical housing units. BSUP housing is a $1 \mathrm{BHK}$ unit ${ }^{11}$, in four storey concrete blocks in grid formation. Vatva has the largest number of said blocks. Not all blocks are occupied, which has created issues with squatting that demands vigilance from the AMC to ensure the swift removal of squatters, unofficial tenants and sub-letters so the resettlement of others to the site occurs with minimal delay. This low income mini-city that already houses around 20,000 people is growing. And, as in the larger city in which it is embedded, social segregation and ghettoisation along religious and caste lines is evident. The three main occupied blocks are informally referred to as 'Hindustan', 'Pakistan' and 'Sri Lanka'12 begrudgingly by many residents who claim the monikers came from outsiders.

\footnotetext{
11 The unit comprises one bedroom, a kitchen, bathroom/toilet and a living room. All units have their own direct water supply, sewerage and electricity connection.

12 'Hindustan' is a mixed area that houses mostly Hindus, though some Muslims live there; 'Pakistan' predominately houses Muslims; 'Sri Lanka' appears an attempt at humour, its residents are a mix of ST and SC, it is said they have darker complexions than other north Indians.
} 


\section{Figure 2: BSUP housing in Vatva}

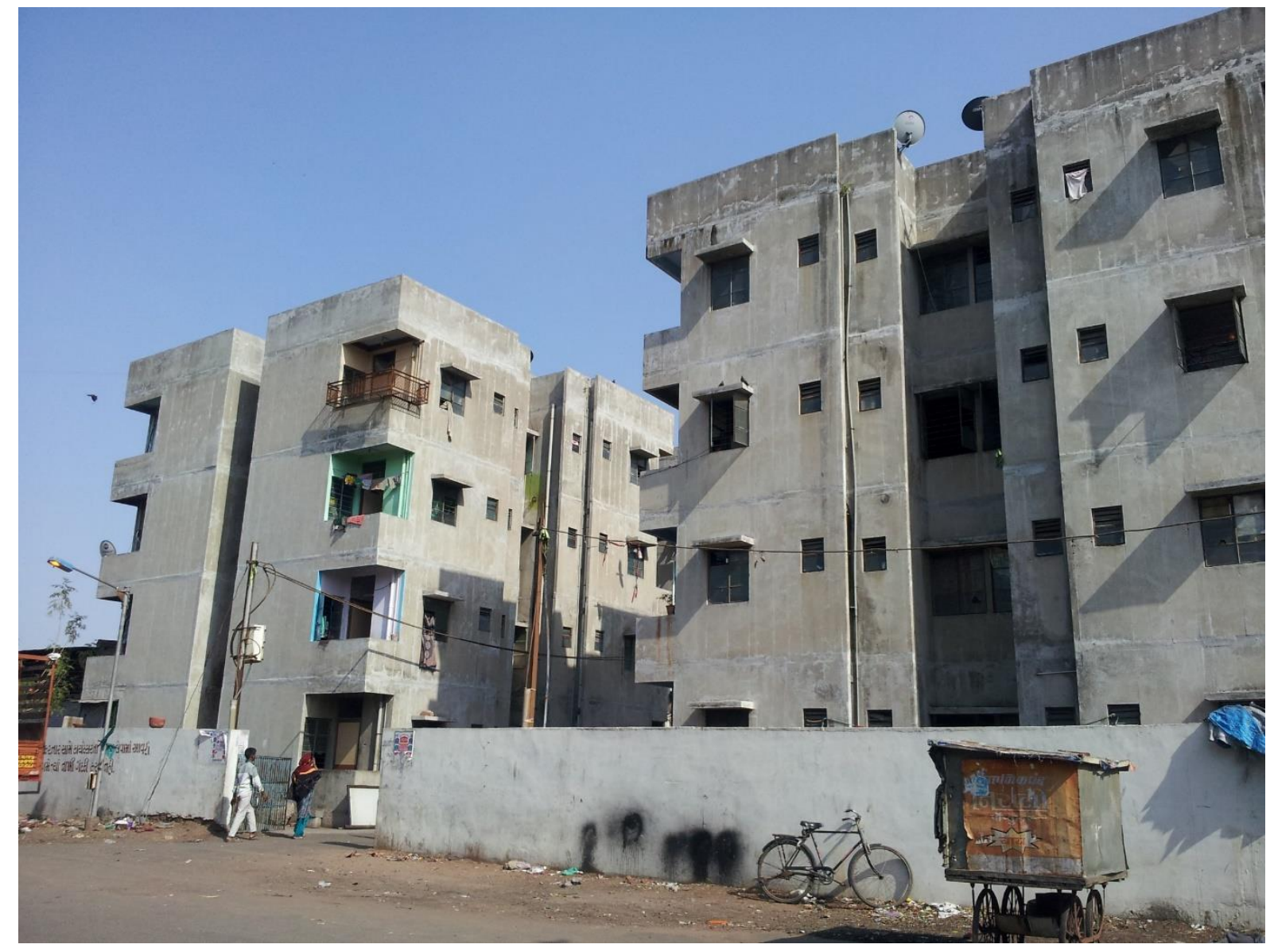

Photo taken by author, April 2014

In the wider context of Ahmedabadi and Gujarati politics, any study into resettlement cannot ignore sinister relocation. Ahmedabad is a communal city. Riots and subsequent displacement have engendered religious and caste-based patterns of settlement in parts of the city, remoulding it into divided and divisive spaces (Chatterjee, 2014; Varadarajan, 2002; Jaffrelot and Thomas, 2012). This paper does not argue that the resettlement of low income Ahmedabadi's - who are overwhelmingly Muslim and lower caste Hindus - from city centre locations to a concentration on the urban periphery is a sinister relocation, but puts forth that in any discussion of resettlement by the state of citizens in communal Ahmedabad, the question of intent and effect must at least be asked either explicitly with a view to answering that question, or implicitly as in this paper, to provoke deeper reflection on the topic. 


\section{Results and discussion of legal tenure security in action}

After people eligible for resettlement to BSUP housing in Vatva had signed their contract with the AMC consenting to the terms and conditions of their new residence and paid their first instalment, they moved in. Families of varying size occupied their $1 \mathrm{BHK}$ and began the process of learning the rules of residence in Vatva. For although they were given written copies of their new terms and conditions which clearly laid out the duties and functions of residents and the AMC, residents report not fully reading or understanding the document. Inside the $1 \mathrm{BHK}$ home of a resident in his late 50s, who lived with his elderly mother, wife and two adult children, he explained he was a literate man and an agavan (community leader) in his former settlement. We spoke in a well-furnished living room which doubled as a bedroom in the evening, overlooked by large prints of the Crucifixion on three of the four walls. He and his family were living on a temporary plot of land for three years before being offered BSUP housing in Vatva. He explained that when he was given the contract to sign,

\footnotetext{
"The AMC did things underhand. They covered the front page and folded the others so we could only see where we had to sign. We didn't read anything before we signed the paper. [...] Most of the other people there [in the temporary site] were living without clean water, the mosquitos were really bad and the shelter wasn't strong. So, when the AMC came and said 'we are giving you a house if you sign here', we all signed! People like us [literate agavans], we didn't even get to read it all” (Interview A, 01/04/14).
}

The significance of the content of the document became apparent much later, when the AMC started to enforce (or threatened to enforce) some of the terms and conditions. 
Table 1 Summary of terms and conditions of residence by theme ${ }^{13}$

\begin{tabular}{|c|c|}
\hline Theme & Select terms and conditions (from a total of 28) \\
\hline $\begin{array}{l}\text { Payment and } \\
\text { affordability }\end{array}$ & $\begin{array}{l}\text { \#4 The value of the property (without the land value) is Rs } 255,000 \text {. Of that, the } \\
\text { resident must pay Rs66,900. } \\
\text { \#5 The AMC finance department will help to provide a mortgage through a bank. } \\
\text { \#7 Monthly instalments to the AMC must be paid in the first } 10 \text { days of the month. } \\
\text { \#9 The electric bill, property tax, the water bill, and any other tax is to be paid by } \\
\text { the resident. } \\
\text { \#22 The instalments must be paid monthly. If residents are unable to pay then the } \\
\text { AMC will take back the property. } \\
\text { \#23 If all instalments are paid, the AMC will transfer the property to the name of } \\
\text { the occupier and they will be given all property documents (dustave). }\end{array}$ \\
\hline Tenure term & $\begin{array}{l}\text { \#6 The resident will be given a } 10 \text { year "lease". Within the } 10 \text { years they are not } \\
\text { allowed to transfer the property to anyone else, sell or rent it. [unless all monies } \\
\text { owed have been paid and they are in possession of property ownership papers] }\end{array}$ \\
\hline $\begin{array}{l}\text { Property } \\
\text { management and } \\
\text { maintenance }\end{array}$ & $\begin{array}{l}\text { \#8 If the resident wants to become a member of the Resident Association, they } \\
\text { must follow its rules. Maintenance charges will go to the Association. } \\
\# 12 \text { The common plot in the settlement must be maintained by residents in the } \\
\text { blocks that surround the common plot. } \\
\text { \#19 In the awarded property if any damage to the property occurs then the AMC is } \\
\text { not answerable, the resident is responsible. }\end{array}$ \\
\hline Occupancy & $\begin{array}{l}\text { \#13 Whoever is allocated the house must live there. It cannot be allocated to } \\
\text { anyone else. They are not allowed to sell or give to rent or pawn the property. } \\
\# 15 \text { The property can only be used for residential purposes not for any other } \\
\text { purpose. }\end{array}$ \\
\hline $\begin{array}{l}\text { Compliance and } \\
\text { enforcement }\end{array}$ & $\begin{array}{l}\text { \#14 Until after } 10 \text { years of occupancy the property belongs to the AMC. For } 10 \\
\text { years the AMC will check the property to ensure rules are upheld. } \\
\text { \#17 Residents are not allowed to file a court case against the conditions of the } \\
\text { property given. } \\
\text { \#24 Under the Public Premises of Unauthorised Occupant Act 1972, if the rules } \\
\text { are not followed then the AMC will vacate the property from the resident. } \\
\text { \#28 Under these rules residents cannot add any further rules or delete any rules } \\
\text { from this. }\end{array}$ \\
\hline
\end{tabular}

The most contentious terms that bring residents and the AMC into a tense standoff are those related to occupancy, payment and property management. They are also the most ambiguously implemented rules largely because residents experience tremendous difficulty in complying with them and the AMC is insufficiently resourced to fully enforce them. This parallel contention and ambiguity creates conditions where many residents are simultaneously fearful of the actions the AMC is likely to take to enforce the rules, and hopeful that there is room to carve a space to negotiate with the municipality on which rules are partially enforced, resulting in a legal tenure security in action that engenders control, fear and finally resistance in Vatva.

13 There is slight variation in the document depending on the precise project that led to resettlement. 


\title{
5.1 Engendering control
}

Control has been exercised largely through the curtailment of residents' choices. The first choice faced by thousands in Vatva was to make a first payment and sign a contract that included a commitment to make regular future payments, or to walk away from the resettlement scheme. The choice was exercised within a context of living in poor conditions or the imminent destruction of their homes. Resettlement for many was a fait accompli. One woman resident in her late 20s, living with her in-laws, husband and three infant children explained,

\begin{abstract}
"It was difficult to find the money to pay for this place, but we had to find it. People were saying if you don't find the money for the first instalment then the property will go from you. Somehow you have to find the money to pay it. For this first instalment we were able to pay because we lived by the [Sabarmati] river and had good job opportunities, so we had some savings and were able to use that to pay. But for the next lot of money we have to pay, how can we pay that?! There are no jobs here, no way to earn an income and now few savings." (Interview B, 03/04/14).
\end{abstract}

She and her family had worked mainly as cooks, catering family functions for wealthier Ahmedabadi families. In Vatva, fewer clients were apparent.

One option supported by the AMC in conjunction with a local NGO (detailed in number 5 of the terms and conditions), is for residents to take out bank loans to make future payments, thus transferring residents' burden of debt from the municipality to banks. Yet, many residents are worried by the burden of a loan. One women resident who sold snacks to local rickshaw drivers and school children at the main entrance of one of the blocks, and who was well placed to comment on the comings and goings of people in the area, remarked,

"There is one madam who comes here to tell us about bank loans... She said 'take a Rs15,000 loan and then pay it back every month and give us a photocopy of your 
papers [that pertain to the property]'. But what are those who have trouble feeding themselves or difficulties in their home to do?! Those people who took a loan are now starving themselves to repay it, what else can they do?” (Interview C, 08/04/14).

Since moving to Vatva from central urban locations, all respondents reported major increases in to their costs of living particularly transport to the city and high electricity bills. All 1 BHK units are fitted with an individual electric meter by Torrent Power (a large private utility company), preventing shared connections between households (a common strategy in previous residences to reduce living costs), resulting in a sharp increase, for one resident, from around Rs500 a month to between Rs1000-1500 a month ${ }^{14}$. All respondents were aware that if an electricity bill was not paid, the company “don't [just] cut the electricity, they remove the whole meter. ... If you want it back you have to pay for it, sometimes double the whole bill" (Interview B, 03/04/14). These increased living costs are accompanied by fewer means of earning an income. For example, the woman food vendor explained (in keeping with number 15 of the terms and conditions),
"You are not allowed to open shops here, but people move around with a cart to sell things then if the police come they can run away with the cart. The police came here recently with the municipality, they told us all 'you're not allowed to run businesses here, don't keep your cart here." "(Interview C, 08/04/14).

Faced with competing demands on income and savings such as making regular payments to the AMC for their property, paying an electricity company that employs aggressive tactics to ensure payment, and buying enough food to eat residents are compelled to rank and choose between their financial responsibilities. The severe consequences of not having access to electricity or food, means that these are prioritised over repaying the AMC. Additionally, in 2014 the AMC

\footnotetext{
${ }^{14}$ In 2015, respondents reported their electricity bills had reduced considerably. They could not explain why (usage being the same) but suspected an error made by the electricity company was corrected.
} 
had yet to meaningfully take steps to secure repayment (a few letters demanding payment were issued to some residents but not to all), and there was widespread belief that the AMC can be negotiated with in a wider context of vote bank politics, whereas electricity companies cannot be.

At least this was the thinking in 2014, by 2015 something had changed - the AMC became more forceful in upholding, or trying to uphold many more of the terms and conditions of residence. This may be partly fuelled by a sense of disbelief among key AMC staff that people cannot pay. In 2014 in an interview with the Mayor of Ahmedabad (also Chairperson of the AMC), when discussing the affordability of BSUP housing, she said, "They pay in instalments. The EWS they give around Rs1 lakh, that's nothing, they have that money. They give Rs1lakh, we're giving them one whole property!" (Spring, 2014). In 2015, following a sustained and aggressive communication campaign in Vatva where residents were given a deadline of $31^{\text {st }}$ March 2015 to make their next payment or face punitive action, AMC officials in the regional office responsible for Vatva saw a steady increase of debtors making repayments, adding credence to the Mayor's sentiment and contributing to the dogged pursuit of residents to make payments. On one of the days I visited the regional office, a queue of around twenty people had formed outside of the door to the clerk's office where payments were made. Inside, the Senior Clerk was opening his ledgers to record payment transactions, preparing ink pads and stamps to press onto receipts and quickly drinking a hot cup of tea. In an office with desk space for at least ten staff, he was alone. Overlooked by Hindu deities taped to the walls and on filing cupboard doors, as soon as his cup was empty the Senior Clerk beckoned the first person in the queue, who unwrapped bundles of notes from a cloth bag which were quickly counted, recorded and receipted. The payee had left in less than a minute with his bag folded under his arm and a receipt in his hand. The Senior Clerk moved swiftly through the line, counting, stamping and answering my questions at the same time. When asked about the affordability of BSUP units, he said, 
"People may say they have no money to pay, but can it really be like that? Their children work, others in their household work... They cannot get a flat for this little amount of money anywhere else." (30/03/15).

When I left the office 30 minutes later, the queue outside had grown and the Senior Clerk was joined by two other colleagues with their own ledgers and receipt books.

Back in Vatva, in an environment that strongly pursues repayment, as found in 2015, the choices between purchasing electricity, food and making repayments have changed. Many respondents felt frightened into finding ways to make repayments, thus locking them into purchasing a property in a place they may not want to live in. The only woman Muslim respondent in the study was living in Vatva with her two teenage daughters and a young son, her husband had left the family several years earlier. The woman and her daughters worked every day in the home sewing dresses and shirts for a clothes merchant; cut fabric was delivered to their home and sewn garment collected a few days later (this was a popular livelihood activity for women in the neighbourhood, although it contravened rules on running businesses from the home). The respondent's eldest daughter was reaching marriageable age which had compounded her stresses in finding a desirable match, paying for a wedding, losing her daughter's labour, and concern over the safety of both daughters. In 2014, she explained, “I want to leave. It's not safe to live here, at night I do not go outside" (Interview D, 11/04/14). She later added,

"Agavans from other places where the AMC has built houses are coming here and offering to swap... I really want to leave here and need to find out if I can swap without paying the Rs20,000 transfer fee [the agavans are demanding] ... If this [opportunity] is real then it would be worth paying the Rs20,000 somehow because at least we'd be back in the city and able to find work... I had a pucca house before by the river. I would want a proper brick house [...] but I know I'm not in a position to 
look for this. I have to move. I feel tension over my girls, not over what kind of house I live in.” (Interview D, 16/04/14).

Officially, at any point residents may return the property to the AMC who will reallocate it, but there is no material or financial gain for residents to do this. In 2015, the respondent was still living in the same property in Vatva, unable to raise the fee to facilitate a property swap and now occupied with finding ways to make repayments. In February and March that year she was visited on two occasions by AMC officials accompanied by the police carrying out checks on the property - these checks entail matching the resident with the name on official papers, checking receipts for any payments made and telling all residents how much is outstanding and when they need to pay by. Auto-rickshaws with loudspeakers attached drive around the area at all times of day telling residents they must pay for their property and remind them of the $31^{\text {st }}$ March 2015 deadline to do so. At our final interview she said she does not know yet how she will pay, only that she knows she must (Interview D, 27/03/15).

\subsection{Engendering fear}

Where the previous sub-section argued that practices of legal tenure security by the state engender control over residents by curtailing choice over where they live including whether they can leave their current residence, this sub-section reviews the same evidence to further argue that control is endued with residents' fear of the state. In legal tenure practices in Vatva the state is made visible to residents through at least three different representations, which I have identified: it has a physical presence in an institutional form (i.e. in buildings and officials); it is present in official documents; and it has a significant presence in rumour and reported actions, which, drawing on Ferguson \& Gupta (2002) and Gupta (2006), all contribute to an everyday understanding of what is 'the state'.

Prevalent practices of illegal subletting and squatting, means that property raids and checks are frequently carried out at random by local AMC officials who are often accompanied by the 
police in groups of between six to ten people. In 2014, the main targets were those who take, “'illegal possession', where we haven't allocated a property and people have just come in and taken over a house. For that we do go to clear the property. For that there is resistance and people are prepared to fight and argue with us... If we have to evict, we ask for police protection." (Head Clerk in the local AMC office, 31/03/14). When experiencing a raid/check or witnessing one, respondents say they cannot discern between the police and the AMC. Despite the police wearing a uniform identifying them as police, and AMC officials wearing ordinary civilian clothing with just a photo card identifying them an AMC employee, their movement in a group and joint purpose seemingly blurs markers that might otherwise distinguish AMC officials from the police. Respondents added, that for every raid where someone is forcibly evicted and a seal placed on the entrance to the property to prevent re-entry, its desperate occupant(s) return a few days later to salvage belongings and seek shelter, thereby ensuring continual raids/checks across Vatva. A minor target of raids/checks were lawful occupants. An AMC Head Clerk explained,

Sometimes we go to sites to visit, to see if these terms and conditions are being upheld. If they are broken then we take back the property. Although, we have not taken back any property yet. [Really though, we know that] of course they won't go! But we have to do it [serve notice on them]... (31/03/14).

However, by 2015, when the AMC's attention shifted to non-payers alongside squatters and sublets, the signs of state authority were already familiar: AMC officials accompanied by the police raiding and sealing properties. In Vatva, there is no visible presence of the AMC outside of raids/checks, or meetings telling residents they must pay for their property, not run businesses from their homes and generally uphold the terms and conditions of their property contracts.

The state is also represented to residents in official documentation. Most residents hold three documents that relate to their tenure and property: the terms and conditions document which is 
a signed contract between resident and the AMC, official receipts for payments made towards the property, and an 'allotment letter' issued by the AMC denoting eligibility for resettlement to Vatva and the number of the housing unit allocated to the household. In raids and checks, all three documents are subject to scrutiny. Of these three, the document laying out terms and conditions is the most communicative about the relationship between the state and citizen and the most important in setting out tenure conditions. In it, the state appears not as a partner in a tenure contract, but as an enforcer. Its responsibilities to protect resident's tenure claim from any rival claim are implicit; what is explicit is the power of the AMC to evict and take punitive action against residents that break any of the terms of their residence (see compliance and enforcement conditions in table 1).

Added to representation in institutions and documents, ideas of 'the state' are present in tenurebased narratives of what the state has (reportedly) done or may do. Despite the fact the AMC has not yet evicted any legitimate resident of Vatva, there remains unease that the AMC can at any time in the future (as it has in their recent past) evict people irrespective of how secure they think they are. One male respondent declared, "I think no one will move us, but we do not have confidence in the municipality that they won't'" (Interview A, 01/04/14). His lack of confidence stems from experience, particularly the underhand manner in which he signed the terms and conditions to the property. Thus, in the bureaucracy of tenure security, 'the state' in both its written and visual representations, is an enforcer of rules. However, there is some uncertainty surrounding the enforcement of all of the tenure terms and conditions giving rise to feelings of mistrust, concern and fear over what the AMC may do, but also hope of room to negotiate.

\subsection{Engendering resistance and the carving of a paralegal space}

In a climate of fear and a sense of loss of control, residents have forged a number of strategies to resist the power exerted by the AMC, particularly around questions of property management and payment. Such strategies focus on non-compliance and selective collaboration that contribute to 
carving a paralegal space where residents are able to renegotiate the rules of their tenure and shape aspects of their own governance. For example, residents are required to forge a Resident Association, which takes responsibility for the collection and spend of maintenance charges levied on all residents, the maintenance and cleanliness of common plots and residential blocks (numbers 8, 12 and 16 of the terms and conditions), and represents a focal point for AMC communications to residents. However, in 2014, resistance to forging such a committee was widespread. One former agavan, a man in his late 40s, explained,

The municipality keep telling us to form [a Resident Association], but I don't think it will happen. No one here wants to work together. [...] Where we lived before in the slums it was ours. We'd lived there for a long time. We had organised ourselves. We'd done deeds for others and established that we worked. Other people trusted us. But here everyone is different; there are Maharatis, Gujaratis, Rajasthanis ... [Also,] if we made an association then we become responsible for the maintenance of the block. The municipality will tell us to look after it and make sure the area is clean, the leaks are repaired and the water works. [...] The worry is if we form an Association the municipality will pass everything on to the Association to fix. (Interview E, $18 / 04 / 14)^{15}$

In this example, non-compliance generated some governance gains, specifically, public health concerns from a high build-up of refuse meant the AMC took back the function of maintaining common plots, despite the terms and conditions placing responsibility on residents and enforcement on the Resident Association, indicating some flexibility in the application of the rules and a little room to manoeuvre. Everyday workers in dark blue jumpsuits wheeled large rubbish bins around the common plots found in the centre of four low rise blocks, sweeping and

\footnotetext{
15 The fears of this respondent seem well placed. In a study on setting up Resident Associations is other resettlement sites in Ahmedabad under the BSUP, Mahadevia, Bhatia and Bhatt (2016:12) conclude, "local government appears to have [set up resident associations in resettlement sites] more with the idea of passing the buck and extricating itself from the responsibilities of managing the rehabilitation sites, than with a genuine desire to equip residents to take on these responsibilities."
} 
collecting refuse that had been thrown out of windows and balconies. There was very little interaction between these workers and residents. No respondent recognised the workers as coming from Vatva and reported they came in the morning, collected the refuse and left a few hours later.

By 2015, although there was still no Resident Association, there was a growing realisation that an Association of representatives of residents could be a useful means to collectively negotiate with the AMC. A year later, another former agavan and close friend of the previous respondent said,

For over five years we've been living here, and the AMC had paid us no attention, so we paid them no attention... But now after 5 years they've stirred us. And so we've started to make a committee [Resident Association]. We've gathered the names of around four people in each block, then we'll try and arrange a meeting with the AMC and see what they say have to say [about our grievances] before we take it further... But we'll have to make a committee at some point, I think. If we don't then the AMC won't ever look our way. Then who will challenge them when they try to do things to us? No one else will do it, so we have to form a committee. (Interview F, 15/04/15).

The realisation that the need for collective action overrides divisive discourses of 'too much difference' amongst Vatva's residents, stems from increased pressure from the AMC on residents to make property payments. Initially, many residents claimed that they did not know they needed to pay. Although one respondent disclosed, "truly we know, we all know. They tell us all the time" (Interview F, 15/04/15). With this increased pressure, there appears to be widespread recognition that any resistance strategy needs more than claims of ignorance. It requires a collective response. The Resident Association, or at least the promise of one, residents hope, will play an important part in re-negotiating payment plans with the AMC. 
The threat of $31^{\text {st }}$ March 2015 was that people must pay their next instalment, or else the property would be sealed and returned to residents only if they can pay the full amount owed; with the option of payment via instalments retracted. "But no one has paid. The $31^{\text {st }}$ has passed, so now we will wait and see what happens next", said a respondent leading efforts at collective action. An experienced political organiser with links to low level BJP officials, he added:

Our hope is that we will get to sit with the AMC Commissioner and ask that he forgives some of the debt and leaves a manageable amount for us. But we haven't sat with him yet.

Q. And do you think you will be able to sit with him? He will sit with us, he has to. He is trying to get money from us, not the other way around. We're already inside the property. We will say to him 'we are ready to make payments, but you have to sit with us and make some agreements, and then we will give it to you'.

Q. Do you think the AMC really will apply a seal? It depends if they follow the legal process, if they do then yes they will apply a seal. But the people living here are such that if a seal was applied they would take to the streets; people will do whatever it comes into their minds to do. Up until now the AMC haven't really been able to do anything [to enforce payment], and if the people get together and come to oppose the AMC well then they still can't do anything. The problem is what if the AMC calls on police protection, then things might escalate. (Interview G, 15/04/15)

There are multiple references to violence (marra mar) and street protests (which would be sizeable given Vatva's population of 20,000 ) that could take place if the AMC were to carry out its threat to seal properties following non-payment. This rhetoric of violence threatens to make spaces ungovernable and in doing so expand spaces of incomplete state governance.

Chatterjee's idea of “zones of paralegal practices" (2004:128) where this incompleteness gives ways to context-specific rules of governance, is relevant to describing the reality of residents' 
security of tenure, which currently exists outside of official rules on the basis of paralegal arrangements (i.e. the continued occupation of property as claim to it upheld through communal support). The renegotiation of tenure rules also takes place outside of the administrative and legal apparatus of the state through direct negotiation with state actors, and is driven by residents so that new norms of fairness, over questions of payment in particular, can exist for the benefit of a wide range citizens resettled to Vatva.

\section{Conclusion: Encountering the state through legal tenure security}

The aims of this paper were two-fold, the first was to understand what the state looks like to residents who have recently come to live under a legal system of tenure security, and the second, to try and explain the state's exercises of power in the field of legal tenure security. As Gupta (2006) has argued, government bureaucracy at its lowest administrative level is how the majority of Indian citizens encounter and give meaning to 'the state'. Thus, municipal bureaucracy on tenure rules, which govern where people live and under what terms and conditions, plays a large role in formulating or re-formulating what the state is to citizens. Examining the bureaucracy of tenure also serves as an examination of the rationalisation of state exercises of power (Brown, 1995/2006). In the case of lawfully resettled citizens to Vatva, the state exerts tremendous control over where they live, locking many into spaces that may be unsuitable or undesirable. Furthermore, the manner in which control is exerted over lawful residents, principally in warnings written into tenure documents and the appearance of forceful implementation of these warnings, engenders fear of the state and of the state's actions should bureaucratic and legal processes be followed through to their end. That hope arises from opportunities to circumvent the rules on tenure and through extra-legal practices, is suggestive of a powerful state bureaucracy.

Turning to the second aim of this paper, to explain the rationale underlying the state's exercises of power in the bureaucracy of tenure, it is pertinent to begin with the assessment that the 
experience of legal tenure security in Vatva does not match common definition of secure tenure: to enjoy or own property without fear of eviction, harassment or other threats (OHCHR, 2009). Given this assessment, there is ambiguity over the aims and objectives of the municipality's (and hence the everyday representation of 'the 'state's') exercises of power over citizens in this field. The conceptual framework outlined three rationales for moving citizens to a legal system of secure tenure: as part of a political settlement, as economic development and/or to manage informality and expand the rational order of the state.

In Vatva, any political settlement where the state upholds housing rights to national or international legislation (the right to life in the Indian Constitution), alongside a progressive commitment to draw socially excluded citizens into a legally protected tenure arrangement, appears compromised or even undermined by the tenure experiences of resettled residents, large numbers of whom simply cannot meet all the terms and conditions of residence. In placing their tenure at risk, residents who are overwhelmingly from ST/SC and other backward caste designations and subject to structural social exclusion, are risking loss of shelter, clean water, a safe electricity supply and monies paid in the resettlement process i.e. the foundations of a right to life.

Legally secure tenure as part of an economic development strategy would suggest residents have the means to take out loans against their property to principally invest in asset-building, and that municipalities have access to a wider revenue base through property tax and/or are able to economically exploit land and real estate released by the resettlement. In Vatva, many residents had taken out loans against their occupancy of property, but the capital appears to have gone towards everyday living costs and property repayments, as opposed to investments to build up the value of assets including the property. As so few had completed their repayments (according to the AMC South Zonal Office where payments are made) and been granted property ownership (dustavej), very few had an obligation to pay property tax. Legal tenure security may yet 
be part of a long term strategy that would see fruition for the municipal tax base but only once full ownership had been awarded at a significant scale; a prospect difficult to imagine in 2015. Real estate development on land released by resettlement to Vatva has moved ahead, but in a manner that completely disconnects resettled citizens from the state (see Mathur, 2012, and Mahadevia, Joshi and Datey, 2013, for examples in the cases of the Sabarmati redevelopment and expansion of the BRTS, respectively), making direct links between urban economic development and these citizen impossible.

The third rationale concerned manging informality by expanding the rational order of the state. From the narratives of Vatva's residents and the actions of the AMC, it is clear that the state through the bureaucracy of tenure displays considerable authority over important parts of people's lives such as where they live, for how long and their means of earning an income, and attempts to discipline residents spending habits by forcing a trade-off where repayment to the AMC ranks higher than electricity, for example. Where resistance to this authority is apparent it is within the implementation of some tenure rules but at a scale that does not challenge the overarching issues of where people live and how they live within their property. This suggests the state is succeeding in expanding its rationalisation of land use and may be committed to expanding rational order by working to develop tenure rules that are both legible and enforceable. But, it is not possible to claim that this is an overt aim of the state. Rather, as James Ferguson (1990) has argued, by studying the state's exercises of power and its effects more broadly by looking beyond official aims and objectives, we can identify unintended outcomes of policy, law and their implementation, as revealing of types of state power and control.

Of parallel importance to this discussion of the official and hidden aims and objectives of state power in tenure security, is a discussion of sinister resettlement. This may be of particular importance if actual security of tenure for resettled citizens is not an attained or seemingly attainable aim or objective of the state. Almost irrespective of whether residents are tenure 
secure is the fact that large numbers of people reside and are likely to continue to reside in Vatva, and their previous residences in prime city locations have been cleared. What remains a pressing question is whether this is for nefarious purposes (and nefarious to whom?), or a simple consequence of making Ahmedabad a megacity.

This empirical study of Vatva suggests that when practices of legal tenure security are placed within a wider context of citizen - state relations, there is cause for concern with what legal property rights enables the state to do unto its citizens with legitimacy, especially its poorer and marginalised citizens, and the effect this has on how such citizens learn of, engage with and understand aspects of the state, adding an important though missing governance dimension to critical debate on tenure regimes. The study also serves as a call for greater scrutiny of the political effects of changes to tenure systems on poor people.

\section{Acknowledgements}

This research was funded through the Urban Knowledge Network Asia (UKNA) - a Marie Curie Actions International Research Staff Exchange Scheme of the European Union - The Bartlett Development Planning Unit's state and market research cluster, and was supported by CEPT University, Ahmedabad. I am grateful to my research assistant Vaishali Parmar for all her efforts, and to Rajendra, Palavi, Harshid, Aanal, Kushal and Prakruti Patel for their extensive support during fieldwork.

\section{References}

Allendorf, K. (2007) 'Do Women's Land Rights Promote Empowerment and Child Health in Nepal?', World Development, 35(11):1975-1988. doi:10.1016/j.worlddev.2006.12.005 
Aloria, G. R. (2013) 'Housing and Urban Poverty Alleviation Scenario', presentation to the Urban Development and Urban Housing Department, Government of Gujarat.

Author (2015) 'Sowing the seeds of conflict? Low income housing delivery, community participation, and inclusive citizenship in South Africa', Urban Studies, doi:10.1177/0042098015572090.

Benei, V. \& Fuller, C.J. (Eds.) (2001) The Everyday State and Society in Modern India, London: Hurst and Company.

Benjamin, S. (2008) 'Occupancy Urbanism: Radicalizing Politics and Economy beyond Policy and Programs', International Journal of Urban and Regional Research 32(3):719-729.

Bhatt, M. (2003) 'Urban Slums Report: The case of Ahmedabad, India' in The Challenge of Slums: Global Report on Human Settlements 2003, Nairobi: UN-HABITAT.

Bhatt, M. \& Chawda, V.K. (1976) 'Housing the Poor in Ahmedabad', Economic and Political Weekly, May, pp.706-711.

Blaikie, N. (2007) Approaches to Social Enquiry, New Delhi: Polity Press.

Blaikie, N. (2000) Designing Social Research: The logic of anticipation, Cambridge: Polity Press.

Brown, W. (1995/2006) 'Finding the Man in the State' in The Anthropology of the State: A reader by A. Sharma and A. Gupta (Eds), Oxford: Blackwell Publishing, pp 187-210.

Chatterjee, I. (2014) 'Social conflict and the neoliberal city: A case of Hindu-Muslim violence in India' in Contesting the Indian City: Global Visions and the Politics of the Local by G. Shatkin (Ed), Hoboken, NJ: John Wiley \& Sons, pp 143-160.

Chatterjee, P. (2004) The Politics of the Governed: Reflections on popular politics in most of the world, New York: Columbia University Press.

Chandhoke, N. (2009) 'Civil Society in Conflict Cities: The Case of Ahmedabad', Working Paper no. 64 Cities and Fragile States, Crisis States Research Centre, London: LSE/DESTIN 
Chauhan, U \& Lal, N. (1999) 'Public-Private Partnerships for Urban Poor in Ahmedabad: A slum project', Political and Economic Weekly, 34(10/11):636-642.

Corbridge, S. \& Harriss, J. (2000) Reinventing India, Cambridge: Polity Press.

Corbridge, S., Srivastava, M., Williams, G. \& Véron, R. (2007) 'Seeing the state again', Geoforum, 38(4):611-613. doi:10.1016/j.geoforum.2006.11.020

Crook, R. \& J. Manor (1998) Democracy and Decentralisation in South Asia and West Africa: Participation, Accountability and Performance, Cambridge: Cambridge University Press.

Desai, R. (2012) 'Governing the Urban Poor: Riverfront development, slum resettlement and the politics of inclusion in Ahmedabad', Economic and Political Weekly, 47(2):49-56.

Earle, L. (2014) 'Stepping out of the Twilight? Assessing the Governance Implications of Land Titling and Regularization Programmes', International Journal of Urban and Regional Research, 38:628-645. doi:10.1111/1468-2427.12112

Ferguson, J. \& Gupta, A. (2002) 'Spatializing States: Toward an Ethnography of Neoliberal Governmentality', American Ethnologist, 29(4):981-1002. doi:10.1525/ae.2002.29.4.981

Ferguson, J. (1990) The Anti-Politics Machine, Minneapolis: University of Minnesota Press.

Fuller, C.J. \& Harriss, J. (2001) 'For an Anthropology of the Modern State', in The Everyday State and Society in Modern India, edited by V. Benei \& C.J. Fuller. London: Hurst and Company, pp. $1-30$.

Ghatak, M. \& Roy, S. (2014) 'Did Gujarat's Growth Rate Accelerate under Modi?', Political and Economic Weekly, 49(15):12-15.

Gilbert, A. (2002) 'On the mystery of capital and the myths of Hernando de Soto - What difference does legal title make?', International Development Planning Review, 24(1):1-19. doi:10.3828/idpr.24.1.1

Gilbert, A. (2012) 'De Soto's The Mystery of capital: Reflections on the book's public impact', International Development Planning Review, 34(3):v-xvii. doi:10.3828/idpr.2012.15. 
Government of India (1949) 'The Constitution of India', available at:http://india.gov.in/mygovernment/constitution-india, accessed 15/05/15.

Government of India (2009) 'Modified Guidelines For Sub-Mission On BSUP, JNNURM', New Delhi: Ministry of Housing and Urban Poverty Alleviation/Government of India, February 2009.

Gulyani, S. \& Bassett, E. M. (2007) 'Retrieving the baby from the bathwater: Slum upgrading in Sub-Saharan Africa', Environment and Planning C: Government and Policy, 25(4):486-515. doi: $10.1068 / \mathrm{c} 4 \mathrm{p}$

Gupta A. (2006) 'Blurred boundaries: The discourse of corruption, the culture of politics, and the imagined state', in The Anthropology of the State: A reader by A. Sharma \& A. Gupta (Eds), Oxford: Blackwell Publishing, pp 211-242.

Hansen, T.B. (2001) 'Governance and the myths of state in Mumbai' in The Everyday State and Society in Modern India, edited by V. Benei \& C.J. Fuller. London: Hurst and Company, pp. $31-67$.

Hansen, T.B. \& Stepputat, F. (Eds.) (2001) State of Imagination: Ethnographic Explorations of the Postcolonial State, London/Durham: Duke University Press.

Home, R. (2004) 'Outside de Soto's Bell Jar: Colonial / postcolonial Land Law and the Exclusion of the Peri-Urban Poor', in Demystifying the Mystery of Capital by R. Home \& H. Lim (Eds.), London: The GlassHouse Press, pp. 11-30.

Holston, J. (2008) Insurgent Citizenship: Disjunctions of Democracy and Modernity in Brazil, Princeton: Princeton University Press.

International Fund for Agricultural Development (2015) 'Land tenure security', Rome: IFAD.

Jaffrelot C. \& Thomas C. (2012) 'Facing Ghettoisation in 'Riot-city': Old Ahmedabad and Juhapura between victimisation and self-help', in Muslims in Indian Cities by L. Gayer and C. Jaffrelot (Eds) New Delhi: Harper Collins, pp 43-80. 
Kanbur R. (2009) 'Conceptualising Informality: Regulation and Enforcement', IZI Discussion Paper 4186, Institute for the Study of Labor, Bonn.

Karst, K. (1971) 'Rights in Land and Housing in an Informal Legal System: The Barrios of Caracas', The American Journal of Comparative Law, 19(3):550-574.

Kothari M., Karmali S. \& Chaudhry S. (2006) 'The Human Right to Adequate Housing and Land', New Delhi: National Human Rights Commission.

Kundu, D. and D. Samanta (2011) 'Redefining the Inclusive Urban Agenda in India', Economic and Political Weekly 46(5):55-63.

Lastarria-Cornhiel, S. (1997) 'Impact of privatization on gender and property rights in Africa', World Development, 25(8):1317-1333. doi:10.1016/S0305-750X(97)00030-2.

Mahadevia, D., Bhatia, N. \& Bhatt, B. (2016) 'Decentralized governance or passing the buck: the case of resident welfare associations at resettlement sites, Ahmedabad, India', Environment and Urbanization 28(1):1-14.

Mahadevia, D., Joshi, R. \& Datey, A. (2013) 'Ahmedabad's BRT System: A sustainable urban transport panacea?', Economic and Political Weekly 48(48):56-64.

Mahadevia, D. (2011) 'Branded and Renewed? Policies, Politics and Processes of Urban Development in the Reform Era', Economic and Political Weekly, 46(31):56-64.

Mahadevia, D. (2002) 'Communal Space over Life Space Saga of Increasing Vulnerability in Ahmedabad', Economic and Political Weekly, November, pp.4850-4858.

Maringanti, A. (2012) 'Urban Renewal, Fiscal Deficit and the Politics of Decentralisation: The Case of the Jawaharlal Nehru Urban Renewal Mission in India', Space and Polity 16(1):93109.

Mathur, N. (2012) 'On the Sabarmati Riverfront: Urban Planning as Totalitarian Governance in Ahmedabad', Economic and Political Weekly 47(47-48):64-75. 
McGowen, A. (2013) 'Ahmedabad's Home Remedies: Housing in the Re-Making of an Industrial City, 1920-1960', Journal of South Asian Studies 36(3):397-414.

Nakamura, S. (2016) 'Revealing invisible rules in slums: The nexus between perceived tenure security and housing investment', Habitat International 53:151-162.

Nandi, S. and S. Gamkhar (2013) 'Urban challenges in India: A review of recent policy measures', Habitat International 39:55-61.

Office of the United Nations High Commissioner for Human Rights (OHCHR) (2009) 'The Right to Adequate Housing', Factsheet 21, Geneva: United Nations.

Payne, G. (2001) 'Urban land tenure policy options: titles or rights?' Habitat International, 25:415429.

Payne, G., Durand-Lasserve, A. \& Rakodi, C. (2009) 'The limits of land titling and home ownership', Environment and Urbanization, 21(2):443-462. doi:10.1177/0956247809344364

Porio, E. \& Crisol, C. (2004) 'Property rights, security of tenure and the urban poor in Metro Manila', Habitat International, 28(2):203-219. doi:10.1016/S0197-3975(03)00068-7.

Robbins, P. \& Rice, J. L. (2007) 'Objects in mirror are closer than they appear: Reflections on Seeing the State (S. Corbridge, G. Williams, M. Srivastava, and R. Véron)', Geoforum, 38(4):608-610. doi:10.1016/j.geoforum.2006.11.017

Robbins, G. (2014) 'Prospects for spatial knowledge tools in municipal budget systems with a focus on property tax issues', Chance2Sustain Policy Brief, October 2014.

Roy, A. (2005) 'Urban Informality: Toward an Epistemology of Planning', Journal of American Planning Association, 71(2):147-158.

Roy, A. (2014) 'The Doctor and the Saint' in Annibilation of Caste by B.R. Ambedkar, New Delhi: Navayana Publishing, pp 15-180. 
Royston L. (2002) 'Security of Urban Tenure in South Africa: Overview of Policy and Practice' in Holding their ground: secure land tenure for the urban poor in developing countries, by A. DurandLasserve, L. Royston (Eds.), London: Earthscan, pp 165-181.

Scott J. (1998) Seeing Like a State: How Certain Schemes to Improve the Human Condition Have Failed, New Haven, CT: Yale University Press.

Sharma A. \& A. Gupta (Eds) (2005) The Anthropology of the State: A Reader, Oxford: WileyBlackwell.

Spodek, H. (2010) 'In the Hindutva Laboratory: Pogroms and Politics in Gujarat, 2002', Modern Asian Studies 44(2):349-399.

Stren, R. (1990) 'Urban housing in Africa: the changing role of government policy', in Housing Africa's Urban Poor by P. Amis \& P. Lloyd (Eds), Manchester: Manchester University Press, pp. 35-53.

The World Bank (2011) 'Land Tenure Policy: Securing rights to reduce poverty and promote rural growth', Washington DC: The World Bank.

Tipple, G. (1994) 'The Need For New Urban Housing in Sub-Saharan Africa: Problem Or Opportunity', African Affairs, 93(373):587-608.

Turner, J. (1976) Housing By People, London: Marion Boyars.

UN-HABITAT (1996) 'Istanbul Declaration on Human Settlements [The Habitat Agenda]', available at: http://ww2.unhabitat.org/declarations/habitat_agenda.asp, accessed $15 / 05 / 15$.

UN-HABITAT (2010) 'Annual Report 2009’, Nairobi: UN-HABITAT.

UKAid (2015) 'A Land Indicator for the SGDs', Land Policy Bulletin Issue 2: October 2015 Van Gelder, J.-L. (2010) 'What tenure security? The case for a tripartite view', Land Use Policy, 27(2):449-456. doi:10.1016/j.landusepol.2009.06.008. 
Van Gelder, J.-L., \& Luciano, E. C. (2015) 'Tenure security as a predictor of housing investment in low-income settlements: testing a tripartite model', Environment and Planning A, 47:485500. doi:10.1068/a130151p.

Van Leeuwen M. (2014) 'Renegotiating customary tenure reform - Land governance reform and tenure security in Uganda', Land Use Policy, 39:292-300. doi:10.1016/j.landusepol.2014.02.007

Varadarajan S. (2002) Gujarat: The making of a tragedy, New Delhi: Penguin Books.

Varley A. (2002) 'Private or Public: Debating the Meaning of Tenure Legalization', International Journal of Urban and Regional Research, 26(3):449-461.

Varley A. (2007) 'Gender and Property Formalization: Conventional and Alternative Approaches', World Development, 35(10):1739-1753. doi:10.1016/j.worlddev.2007.06.005

Weinstein, L. (2009) 'Democracy in the Globalizing Indian City: Engagements of Political Society and the State in Globalizing Mumbai', Politics and Society, 37(3):397-427.

Yagnik A. \& S. Sheth (2011) Abmedabad: From Royal City to Megacity, New Delhi: Penguin Books. 